was the recognised standard for general engineering purposes. Prior to that, each firm had its own 'standard' set of screwing tackle, the existence of which made engineering repairs costly and inconvenient. Owing to the pre-eminent position occupied by British engineering, the establishment of a British system was very favourable, and no difficulty was experienced in securing the adoption of Whitworth screws in Germany and the United States.

The two great attacks made on the Whitworth system came from the Franklin Institute in 1864, when the Sellers thread was adopted and recommended to American engineers, and in 1873, when Delisle of Karlsruhe initiated a metric system. In 1918 the International Screw Thread Congress adopted the international metric screw thread. Now the metric system of screw threads is standardised on the continent of Europe, America has its Sellers standard, whilst Great Britain retains the Whitworth system.

It is said that the threads now recognised as standards are included in about eight great systems, but a popular handbook gives details of no fewer than thirty different kinds of screw thread. As an example of the practical confusion arising, Mr. Watson says that if we place side by side a half-inch American screw, an English half-inch screw, and a $12 \mathrm{~mm}$. screw ( $2 \mathrm{~mm}$. pitch), it is not easy to note the difference. The American screw has, however, 13 threads to the inch, the English 12, and the metric 13.7, and the angles are $60^{\circ}, 55^{\circ}$, and $47.5^{\circ}$ respectively ; therefore each must have its special nut. As in these days engineers are constantly handling the products of other countries, and as two different systems of screws may be employed on the same machine, much time is wasted in finding the standard used and in trying to get a screw conforming to that standard.

A similar difficulty is experienced in wire and sheet metal gauges. It may be suggested that the time is ripe for the various bodies concerned to examine all sides of the question, with the view of securing the adoption of an international system of measures for all commercial purposes.

\title{
Embryology of the Slime Eels*
}

$\mathrm{T}$

HE Myxinoidea or slime eels have been the subject of inquiry and discussion by many investigators in both Europe and America. Much difference of opinion for a long time existed, and even yet remains, with regard both to the facts concerning them and to their interpretation. So little were these animals at first understood that the earliest investigators classified them with the worms. This error was early rectified, but great controversy continued to centre round such questions as whether the Myxinoids are or are not parasitic, whether they are primitive or degenerate, and whether they should be classified as Gnathostomata or Agnathostomata.

On the last question agreement had almost been reached, most morphologists and embryologists having placed them in the former group, when recently a sole investigator who has arisen in the field of myxinoid palæontology, stoutly claims for them a place in the latter. The excretory system has been described by some workers as a pronephros, by others as a pronephros which eventually becomes transformed into a mesonephros, and by still others as a small pronephros and a posterior segmental mesonephros which develops in the usual manner. The reproductive system, too, has been very extensively studied. Because of peculiarities in the structure of the generative organ, the myxinoids have long been believed to be functional hermaphrodites-in fact, they are still definitely stated to be so in even the most recent textbooks.

For many years the assistance of embryology in solving these and other problems connected with this difficult group was denied, because no one was able to find embryos developing in their natural environment or to obtain them by keeping the 'eels' in captivity. Neither did palæontology contribute towards their elucidation, for until quite recently no fossil cyclostome had been found-with the possible exception of Palcespondylus, supposed by some to be a Devonian lamprey. This belief, however, was firmly rejected by Dr. Bashford Dean, by whom many valuable contributions to our knowledge of the Myxinoidea were made during the time that he was professor of zoology at Columbia University.

From examination of his notebooks, it seems quite

* The Bashford Dean Memorial Volume. " Archaic Fishes." Edited by E. W. Gudger. Article 3: The Genital System of the Myxinoidea a Study based on Notes and Drawings of these Organs in Bdellostome made by Bashford Dean. By Prof. J. Leroy Conel. Pp. 63-102+4
plates. (New York: American Museum of Natural History, 1931.) certain that this industrious and talented investigator had intended some day to publish still further information which he had gleaned, especially on the genital system of Bdellostoma. It is particularly fitting, therefore, that the Bashford Dean Memorial Volume on "Archaic Fishes" should contain this section on the Myxinoidea based on the unpublished data left by Dr. Dean in the form of notes, graphs, tables, and sixteen excellent drawings. This contribution to the volume is written by Prof. Leroy Conel, who for twelve years was associated with Dr. Dean in his work.

This author, before presenting Dr. Dean's notes and data (dealing mainly with the reproductive system of Bdellostoma), gives a brief but very useful review of the previous literature on the subject, in which the problems which Dr. Dean set out to solve are clearly indicated. Myxine glutinosa, the representative of the group mainly studied by previous workers, was stated by Nansen (1887) to be a functional protandric hermaphrodite. Cunningham (1891), though disagreeing with some of Nansen's observations, came to the same conclusion. In 1899 Dr. Dean published a paper in which he expressed grave doubts as to the truth of this assumption-doubts which were later supported in the publications of A. and K. E. Schreiner (1904-8). These authors held that, though undoubtedly hermaphrodite in structure, Myxine is functionally diœcious.

On account of this uncertainty concerning the true state of affairs in Myxine, Dr. Dean, in search of further evidence, turned his attention to other members of the group, Bdellostoma stouti and B. burgeri. In these he found the gonad of each individual examined to be definitely either a testis or an ovary, and concluded that both species of Bdellostoma, at least, are very rarely, if ever, hermaphrodite at any stage of their life history. This finding, he contended, made it still more difficult to believe that the closely related Myxine is a functional hermaphrodite. In 1896, in order still more fully to investigate the life history of the Myxinoidea, Dr. Dean sought for, and succeeded in finding, a large number of embryos of $B$. stouti at Pacific Grove, in Monterey Bay, California-the first fairly complete series of myxinoid embryos ever collected. This material enabled him, in 1899 , to publish an account of the embryological development of this species. In 1900 and 1901 he made a similar, though less successful, attempt to

No. 3260, Vor. 129] 
collect embryos of $B$. burgeri along the coast of Japan.

While searching for embryos, Dr. Dean recorded in his field notes many observations which contribute towards answering the question of the breeding season and spawning period of these species. From the data thus collected he came to the conclusion that the spawning time of Bdellostoma is during late August, all of September, and the first three weeks of October. This finding is completely at variance with a statement made by him in 1899, in which he says that "embryos can be obtained during the late fall and early winter in stages which enable me to extend the known season of ovulation throughout the whole year. A time of optimum spawning probably occurs; and this I believe to be the last of spring and the first month of summer." In the absence of more definite data from other workers, these two differing views serve but to emphasise the fact that the spawning time of the Myxinoidea is still unknown.

All investigators in these and allied fields of research will be exceedingly grateful to Prof. Conel for collecting and arranging these notes, graphs, and drawings of the late Dr. Dean, and to the trustees of the American Museum who have made possible their publication. Here and there in the paper the writer has added some of his own observations and conclusions. For the purpose of presenting more clearly and of emphasising the significance of Dr. Dean's work, this was perhaps necessary-oven inevitable. Nevertheless, although Prof. Conel's contributions consist chiefly of corroborations of Dr. Dean's observations, it is unfortunate that not infrequently the reader is provided with insufficient clues to enable him to decide which of them is responsible for a given observation or deduction.

G. A. S.

\section{University and Educational Intelligence}

London.-The degree of D.Sc. in Chemistry has been awarded to Mr. A. A. Goldberg (Imperial College - Royal College of Science) for a thesis consisting of three papers entitled (1) "The Synthesis and Orientation of Trichloroanthraquinones and Amino Disulphonates of Anthraquinone ", (2) "The Rational Synthesis of $1: 3$ Dichloroanthraquinone", and (3) "The Reduction of Nitroanthraquinone Sulphonic Acids" (J. Chem. Soc., 1931-32).

OF the State school supervisory agencies used by local education authorities in America one of the most important is the circular letter. A collection of specimen letters, addressed chiefly to rural school teachers, is published as Bulletin No. 19, 1931, of the Office of Education, Washington. They give some idea of how the wheels of the State school machine go round, and of the multifarious duties that fall to the lot of the school superintendents, some thousands of whom assembled in February at Washington under the auspices of the National Education Association. The February number of School Life, the organ of the Federal Office of Education, is devoted largely to topics of special interest to them.

THe "Hygiene and Physical Education" chapter of the fortheoming Biennial Survey of Education in the United States, 1928--1930, has been issued as Bulletin No. 20, 1931, of the Office of Education, Washington, and almost simultaneously has appeared "White House Conference, 1930 : a condensed report of America's children, their health, education, training handicaps, etc., as analysed by 1200 experts working on 150 committees", obtainable (price 50 cents) from the office of the White House Conference on Child
Health and Protection, Interior Department Building, Washington, D.C. There has recently been conducted in connexion with this conference an investigation, such as has not taken place since 1923, of American public school medical and dental work and health and physical education, and the results of the investigation are summarised in this bulletin. It appears that in such matters as high school playgrounds, gymnasia and swimming-pools, and health examination of children attending, or soon to attend, elementary schools, there has been during the past seven years a marked improvement. In universities and colleges the answer to " the insistent demand that students should know more about wise living and the care of their bodies" seems to have been in most cases rather perfunctorily met by optional courses in hygiene, and college entrance requirements have, through lack of recognition for entrance credit of physiology and hygiene, tended to distract attention from the needs of health teaching in secondary schools. There has been in recent years a remarkable development of interest on the part of colleges, universities, and teachers' colleges in summer camps and the opportunities they offer of health cultivation.

\section{Calendar of Geographical Exploration}

\section{April 25, I900.-Italian Polar Expedition}

Capt. Cagni reached $86^{\circ} 34^{\prime} \mathrm{N}$. in $65^{\circ} 20^{\prime} \mathrm{E}$. The Italian expedition of H.R.H. Prince Luigi, Duke of the Abruzzi, had sailed in 1899 in the Stella Polaris by way of Franz Josef Land. The winter was spent in Teplitz Bay, Rudolf Island, and in the spring an attempt was made to reach the north pole by sledging over the ice. Frost-bite disabled the Duke, and Capt. Cagni therefore led the northern party, starting on March 10, 1900, with ten men and nearly a hundred dogs. Before losing sight of Rudolf Island, three men turned back - and were never seen again. A second party returned safely from lat. $83^{\circ} 10^{\prime} \mathrm{N}$., but Cagni, with three companions, reached the above point: no land was visible at the farthest north. Cagni had to turn back because the food supply was giving out; the return journey took sixty days, as against forty-five for the outward. Much had been achieved, though the pole itself had not been reached.

\section{April 26, I848.-A. R. Wallace and H. W. Bates}

A. R. Wallace and H. W. Bates left Liverpool for Para, where they stayed for eighteen months, and thence made excursions to the Tocantins, Cameta, and the junction of the Rio Negro and the Amazon. Thence Wallace went to the Orinoco, and returned to England in 1852. Bates proceeded up the Amazon to Ega, where he remained for a year. In October 1857, Bates again set out from Para, and settled at Santarem for three and a half years, from which point he made numerous expeditions. For another four years he was at Ega, and then set out on an expedition to the foot of the Andes; but at Fonteboa he was compelled by illness to return, after having travelled 1400 miles up the great river. His book, "The Naturalist on the Amazons", is not only of scientific value, but also has a charm which still attracts the general reader. During his eleven years' stay he collected 8000 species of insects new to science. Wallace's collections, except for some sent on in advance, were lost in a fire at sea on the return journey. In 1854-62, Wallace made a tour in the Malay Archipelago. He divided it into two groups, according as their zoological affinities were Oriental or Australian. A narrow belt of sea, known as 'Wallace's Line', between the Oriental Borneo and 